\title{
標的絶対定量的プロテオミクスに基づくPharmacoproteomics：国際共同研究の重要性
}

\author{
寺崎哲也
}

\section{Quantitative Targeted Absolute Proteomics (QTAP) -based Pharmacoproteomics: The Importance of International Collaboration}

\author{
Tetsuya Terasaki \\ Membrane Transport and Drug Targeting Laboratory, Graduate School of Pharmaceutical Sciences, \\ Tohoku University; 6-3 Aoba, Aramaki, Aoba-ku, Sendai 980-8578, Japan.
}

(Received October 17, 2016)

\begin{abstract}
Proteins such as membrane transporters, enzymes, receptors and channels play key roles in drug absorption, distribution, metabolism, and elimination, and also influence efficacy and the likelihood of adverse reactions. Therefore, if we can quantify the activities of these molecules, it may be possible to predict the behavior of candidate drugs in humans in disease states; such methodology would be extremely helpful for efficient drug development. We have developed an in silico method to select appropriate peptides within amino acid sequences in order to quantify targeted proteins by LCMS/MS in selected reaction monitoring (SRM) mode. We have applied this method for the quantification of functional proteins in order to validate various in vitro and in vivo models. We found fairly good correlation between protein amounts and the enzymatic activities of microsomal cytochrome P450 (CYP) isoforms and uridine 5'-diphosphoglucuronosyltransferase (UGT) in human liver, as well as between protein amounts and the transport activities of multiple transporters in human lung cells. These results suggest that protein quantification can be useful in predicting activity. We have applied this approach to evaluate the usefulness and limitations of an immortalized human brain capillary endothelial cell line (D3 cells) and a P-glycoprotein humanized ( $h M D R 1$ ) mouse model by comparing the amounts of functional proteins in the models with those in isolated capillaries from human brain. In order to obtain sufficient human tissue specimens for further studies leading to clinical applications, we believe that international collaboration will be crucial.
\end{abstract}

Key words_ - pharmacoproteomics; protein quantification; targeted proteomics; blood-brain barrier

\section{はじめに}

細胞や臓器の機能はタンパク質が担っており，機 能の本質の理解には，「修飾型を含むタンパク質の 発現量に基づく活性の理解」は必須である。輸送担 体，酵素，受容体，チャネルなどのタンパク質は薬 物の輸送，代謝，排泄，効果，副作用を決定する要 素であり，それらの絶対発現量やアミノ酸修飾量や 細胞内局在状態や複合体形成状態などを解明するこ となくして，その生体内活性を予測することは不可 能である (Fig. 1)。創薬科学における究極的課題 の 1 つは病態時のヒトに薬物投与後の体内動態と薬 効毒性を予測することである。リバーストランス

東北大学大学院薬学研究科薬物送達学分野 (T9808578 仙台市青葉区荒巻字青葉 6-3)

e-mail: terasaki.tetsuya@m.tohoku.ac.jp

本総説は, 日本薬学会第 136 年会シンポジウム S01 で

発表した内容を中心に記述したものである。
レーショナルリサーチの成功確率を高めるためには 基礎研究と臨床研究を隔てる大きなギャップを埋め る必要があり，これらの点についてオルガネラと細 胞の違い, 細胞と臓器の違い, 動物種間の違い, 加 齢の違い, 性の違い, 各種病態時の違い, 薬物投与 時の違いなどを明らかにする必要がある.11)

タンパク質定量用ペプチドをアミノ酸配列に基づ いて in silico で選択することで遺伝子データベース があるすべての生物種のタンパク質定量を実現

高速液体クロマトグラフィーを連結した三連四重 極型質量分析装置は低分子化合物の高感度定量に適 しており，多くの実績がある，従来のプロテオミク ス研究は血漿タンパク質など水に可溶性のタンパク 質が主流であり，水に難溶性の細胞膜タンパク質な ぞの研究は後回しにされてきた. 一方, 膜タンパク 質は種々の機能を持っており創薬科学において極め て重要であることから, 私達は膜タンパク質の配列 


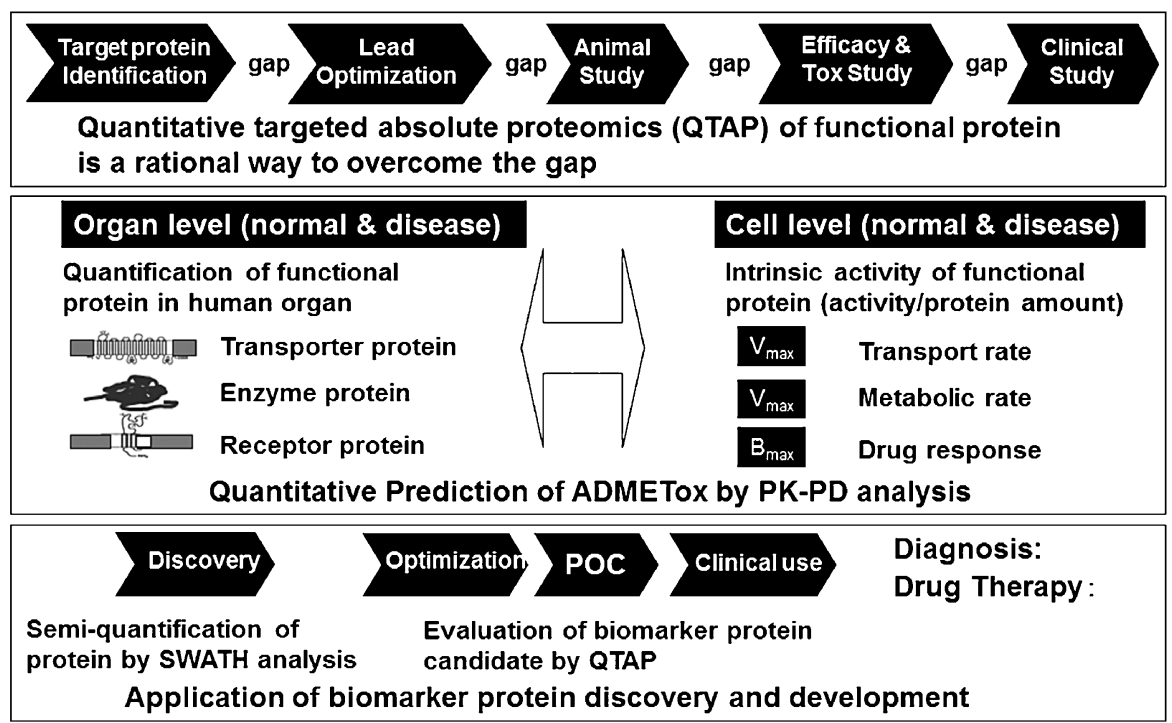

Fig. 1. Quantitative Targeted Absolute Proteomics (QTAP) Based Pharmacoproteomics: Application of Protein Quantification for Drug Discovery, Development and Therapeutics

から細胞膜貫通領域を除いた部位に着目し，トリプ シン消化産物の中から標的タンパク質に特異的な配 列のペプチドを選択し，さらに質量分析装置で比較 的強いシグナルを出す可能性が高いペプチドを選択

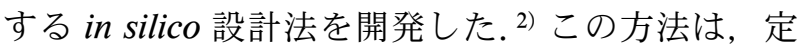
量したいタンパク質がなくても定量法を確立できる 長所がある. 遺伝子配列のデータベースが存在する すべての動物種についてタンパク質の定量法の確立 が可能になり, 定量プロテオミクスの研究速度を飛 躍的に加速できるようになった．詳細なプロトコル を公開しており参考願いたい. ${ }^{3)}$

タンパク質の活性予測には mRNA よりもタンパ ク質の定量が必要

ヒト肝臟ミクロゾームの CYP と UGT について タンパク質と mRNA を定量し，その薬物代謝活性 と比較したところ CYP3A4, CYP2B6, CYP2C8 は mRNA とタンパクの発現量は良好な相関があった が，それ以外の酵素では相関性が低かった。さら に，ほとんどの酵素において代謝活性と発現量の間 にはタンパク質の方が mRNA よりも高い相関性が あった. ${ }^{4)}$ さらに最近の肺を対象とした研究によっ て，輸送担体タンパク質の発現量とその輸送活性の 間に高い相関性があることが分かった。 5 これらの 結果から, タンパク質の機能の定量的予測には当該 タンパク質の発現量の測定が必須であることが示さ れた。

タンパク質定量によって in vitro 実験系の有用性 と限界を評価できる

In vitro 培養細胞の機能が臓器レベルをどれだけ 反映しているかを評価することは重要な課題であ る. ヒト単離脳血管とヒト脳毛細血管不死化細胞株 （D3 cell line）について各種輸送担体タンパク質の 発現量を測定し, $\mathrm{Na}^{+} / \mathrm{K}^{+}$ATPase の発現量に対す る比で比較したところ, GLUT1, MCT1について ほぼ両者が一致した. ${ }^{6,7)}$ BCRP, MDR1, Claudine 5 などでは単離血管に比べ D3 細胞の方がやや少なく,

ENT1 やトランスフェリン受容体は多く発現してい た。 D3 細胞は大学だけでなく企業を含めて世界で 最も多くの研究室で使用されているヒト in vitro 血 液脳関門モデルであり，この結果によってその有用 性と限界を定量的に評価することができた.

タンパク質定量によって遺伝子改変動物の有用性 と限界を評価できる

遺伝子改变動物について当該タンパク質のみなら

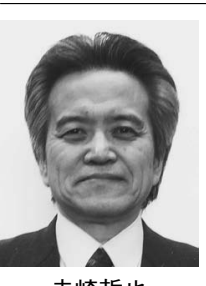

寺崎哲也
1955 年富山に生まれ, 金沢大学薬学部 を卒業し, 東京大学大学院薬学系研究 科博士課程修了後, 東京大学助教授を 経て, 1996 年から東北大学教授を務め る.これまで, Ebert 賞, AAPS Meritorious Manuscript 賞, 紫綬敦章, 日本薬 学会賞, Highly Cited Researchers 2016 などを受賞し，2015 年東北大学 Distinguished Professorの称号を授与される. 


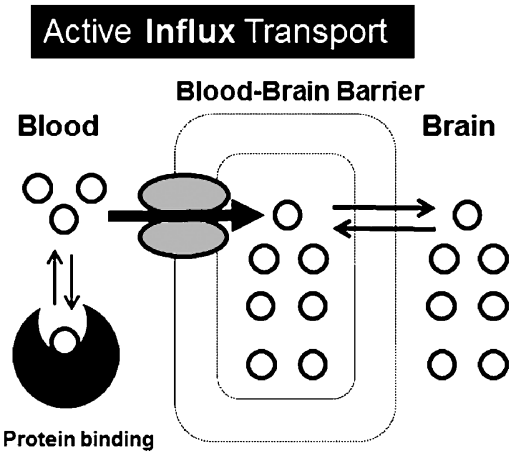
Drug delivery to the brain by increasing affinity to active influx transport system

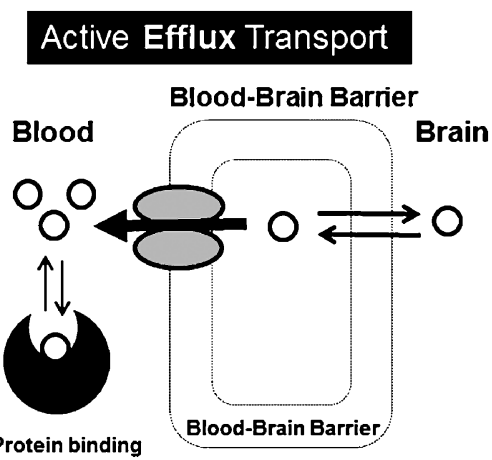

Drug delivery to the brain by decreasing affinity to active efflux transport system

Fig. 2. Unbound Drug Concentration Gradient between Brain and Blood Is Generated by Active Transport System in the BloodBrain Barrier

ず関連タンパク質の発現変動を定量的に評価するこ とはモデル動物の創薬研究への活用において非常に 重要である. Mdrla/b (-/-) や bcrp $(-/-)$ や $m d r l a / b(-/-)$ bcrp (-/-) の gene knockout mouse は P-gp や bcrp の基質候補薬物について 脳内移行性をin vivo で評価する上で有用なモデル 動物である.これらのマウス脳毛細血管内皮細胞に おける当該タンパク質の発現量は検出限界以下であ るとともに，種々の abc や slc transporter や受容体 タンパク質の発現は正常マウスと同じであった. ${ }^{8)}$ したがって，当該タンパク質のみの役割を評価でき るモデル動物であることが示された。一方， Taconic Artemis 社においてマウス mdrla gene を knockoutしヒト MDRI gene を導入した C57BL/6 humanized MDRI（hMDRI）マウスについて私達 の研究室で解析したところ, 脳毛細血管における MDR1 タンパク質の発現量は $0.355 \mathrm{fmol} / \mu \mathrm{g}$ protein とヒト脳毛細血管における発現量 $6.06 \pm 1.69$ $\mathrm{fmol} / \mu \mathrm{g}$ protein に比べて 17 分の 1 と低かった. ${ }^{9)}$ さらに，驚くべきことに gene knockoutしたにもか かわらず $h M D R 1$ マウスにおける mdr1a の発現量 は導入した MDR1 タンパク質の 6.9 倍も多い 2.45 $\pm 0.19 \mathrm{fmol} / \mu \mathrm{g}$ protein であった。正常な $\mathrm{C} 57 \mathrm{BL} / 6$ マウス脳毛細血管における mdr1a の発現量 $22.3 \pm$ $2.9 \mathrm{fmol} / \mathrm{ug}$ protein と比べると $11 \%$ が残つていた ことになる。この結果は当該動物を用いた pharmacokinetic の解析結果と一致していた. したがつ て, mdrlaの knock out 方法に問題があったために 輸送活性を保持したタンパク質の一部が脳毛細血管
で機能し, knock in 遺伝子のヒトMDR1 の発現が 極めて低かったためにヒト化が成功しなかったこと が証明された. ${ }^{9)}$ 遺伝子改変動物に限らずモデル実 験系の評価において決定的な手法であることが証明 された.

タンパク質の発現量とタンパク質当たりの固有活 性を測定することで in vivo 活性を再構築できる

臟器レベルのタンパク質の活性をその発現量と夕 ンパク質当たりの固有活性に基づいて再構築するこ とは動物のみならずヒトの病態時のタンパク質活性 の予測において非常に重要な課題である。Mdr1a gene knockout mouseに 11 種類の薬物を投与後の 血漿と脳中薬物濃度比を求め, 同様に測定した正常

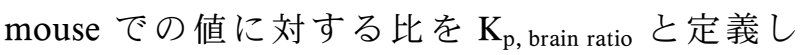
た。この值は脳内非結合型薬物濃度に対する血漿中 非結合型薬物濃度の比率を表し，この濃度勾配は血 液脳関門における mdr1a の活性によって作られて いる（Fig. 2)。マウスの血液脳関門の実体である 脳毛細血管に発現する $\mathrm{mdr} 1 \mathrm{a}$ の発現量 $\left(\mathrm{C}_{\mathrm{mdr}} 1 \mathrm{a}, \mathrm{B}\right.$-cap $)$ と mdrla 遺伝子導入培養細胞における $\mathrm{mdr} 1 \mathrm{a}$ の発 現量 $\left(\mathrm{C}_{\mathrm{mdr} 1 \mathrm{a}, \mathrm{cell}}\right)$ を測定した。ささらに mdrla 遺伝 子導入培養細胞とその宿主細胞を用いて 11 種類の 薬物について apical-to-basal と basal-to-apical の各 透過速度の比を測定し, 遺伝子導入細胞での測定值 に対する宿主細胞での測定值の比率として定義した corrected flux ratio を求めた. これらの值を次式に

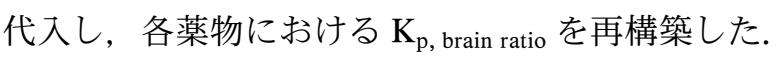

$\mathrm{K}_{\mathrm{p} \text {, brain ratio }}=1+($ corrected flux ratio -1$) \times$

$\left(\mathrm{C}_{\text {mdr1a, B-cap }} / \mathrm{C}_{\text {mdr1a, cell }}\right)$ 
11 種類 (quinidine, loperamide, digoxin, risperidone, indinavir, dexamethasone, vinblastine, paclitaxel, verapamil, loratadine, diazepam) の薬物につ いて，いずれも in vivo の值と再構築した值はほぼ 一致した. ${ }^{10)}$ さらに，カニクイサルを用いて 6 種類 (quinidine, loperamide, indinavir, paclitaxel, verapamil, diazepam) の薬物について検討した。 ただ し，脳スライスを用いて定常状態における脳スライ ス中薬物に対するメディウム中薬物の濃度比から脳 内非結合率を測定し，平衡透析法を用いて血漿非結 合率を測定した。これらの值を用いてサルの血漿に 対する脳内の薬物濃度比 $\left(\mathrm{K}_{\mathrm{p}, \text { brain }}\right)$, 血漿中に対す る脳内の非結合型薬物濃度比 $\left(\mathrm{K}_{\mathrm{p}, \text { uu brain }}\right)$ について

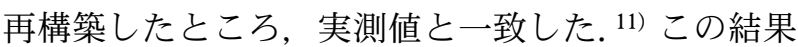
は霊長類であるサルにおいても in vivo の P-gp の 活性を再構築することができたことを示す。さら に，自然発症てんかんマウス (EL mutant mouse) と pentylenetetrazole-kindled てんかんマウス, phenytoin 投与マウスについて単離した脳毛細血管 中の mdrla タンパク質量を測定したところ, 各々 $16.4 \pm 0.7,14.8 \pm 0.6,22.1 \pm 0.6(\mathrm{fmol} / \mu \mathrm{g}$ protein $)$ であった．正常マウスでは $11.5 \pm 0.1 （ \mathrm{fmol} / \mu \mathrm{g}$ protein）であり，いずれも mdr1a が誘導されてい た. 各モデル動物に verapamil 投与後の $\mathrm{K}_{\mathrm{p} \text {, brain }}$ 測定し， mdr1a の活性が正常と同じであると仮定

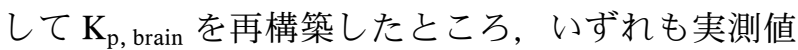

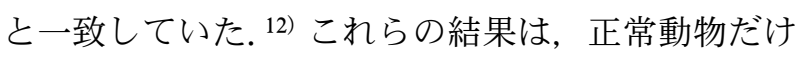
でなく病態動物や霊長類においても in vivo のタン パク質の活性をタンパク質の発現量に基づいて再構 築できることを証明したものである。 ヒトの病態時 の予測へ大きく近づいたと考えられ，リバーストラ ンスレーショナルリサーチをさらに加速することが 期待される.

おわりに

本総説で紹介した成果の一部は4,7-9) 国際共同研究 によって得られたものであり，日本国内でも積極的 に共同研究を行っているが入手が困難な疾患組織や ヒト化モデルを対象とした研究の幅を広げることが できる．現在，欧米 7 力国 14 施設と共同研究体制 を構築して脳腫瘍，てんかん，アルツハイマ一病な どにおける pharmacoproteomics 研究を展開中であ る.わが国の学術成果を世界に発信し国際的プレゼ ンスを高めるためには世界が求める独自の研究手法
を開発し研究展開することが大切である.

利益相反 タンパク質の定量に適したペプチド をin silico で設計する手法に関する特許は東北大学 特許として登録されており筆者は発明者の一人であ る、筆者が取締役を務める Proteomedix Frontiers 社は東北大学 TLO に対して当該特許実施料を支払 つている．本総説で紹介したすべての成果は同社の 事業と無関係に得られたものである。引用文献 5 の 成果は筆頭著者が社会人博士課程学生として筆者の 研究室に在籍中に得られた成果の一部である.

\section{REFERENCES}

1) Ohtsuki S., Uchida Y., Kubo Y., Terasaki T., J. Pharm. Sci., 100, 3547-3559 (2011).

2) Kamiie J., Ohtsuki S., Iwase R., Ohmine K., Katsukura Y., Yanai K., Sekine Y., Uchida Y., Ito S., Terasaki T., Pharm. Res., 25, 1469-1483 (2008).

3) Uchida Y., Tachikawa M., Obuchi W., Hoshi Y., Tomioka Y., Ohtsuki S., Terasaki T., Fluids Barriers CNS, 10, 21 (2013).

4) Ohtsuki S., Schaefer O., Kawakami H., Inoue T., Liehner S., Sato A., Ishiguro N., Kishimoto W., Ludwig-Schwellinger E., Ebner T., Terasaki T., Drug Metab. Dispos., 40, 83-92 (2012).

5) Sakamoto A., Suzuki S., Matsumaru T., Yamamura N., Uchida Y., Tachikawa M., Terasaki T., J. Pharm. Sci., 105, 876-883 (2016) .

6) Uchida Y., Ohtsuki S., Katsukura Y., Ikeda C., Suzuki T., Kamiie J., Terasaki T., J. Neurochem., 117, 333-345 (2011).

7) Ohtsuki S., Ikeda C., Uchida Y., Sakamoto Y., Miller F., Glacial F., Decleves X., Scherrmann J. M., Couraud P. O., Kubo Y., Tachikawa M., Terasaki T., Mol. Pharm., 10, 289-296 (2013).

8) Agarwal S., Uchida Y., Mittapalli R. K., Sane R., Terasaki T., Elmquist W. F., Drug Metab. Dispos., 40, 1164-1169 (2012).

9) Sadiq M. W., Uchida Y., Hoshi Y., Tachikawa M., Terasaki T., Hammarlund-Udenaes M., PLoS One, 10, e0118638 (2015).

10) Uchida Y., Ohtsuki S., Kamiie J., Terasaki T., J. Pharmacol. Exp. Ther., 339, 579-588 
(2011).

11) Uchida Y., Wakayama K., Ohtsuki S., Chiba M., Ohe T., Ishii Y., Terasaki T., J. Phar- macol. Exp. Ther., 350, 578-588 (2014).

12) Uchida Y., Ohtsuki S., Terasaki T., Drug Metab. Dispos., 42, 1719-1726 (2014). 